\title{
What indicators have been used to evaluate the impact of music on the health and wellbeing of people with dementia? A review using meta- narrative methods
}

\author{
Becky Dowson (University of Nottingham), Orii McDermott (University Of Nottingham), \\ Justine Schneider (University Of Nottingham)
}

\begin{abstract}
This review considers how research into the impact of music upon people with dementia has been conducted, with a focus on the means used to measure outcomes Although there is a rapidly-growing amount of research in this relatively new area, it has evolved fairly separately within different fields, such as psychology, music therapy and nursing. Using principles from the meta-narrative review method, this paper systematically surveys qualitative and quantitative measures which have been used in studies relating to music and dementia from 1980 to the present day. Data extracted included the outcome measures used, the type of music intervention, the setting of the studies and methodology and study design. Results showed that quantitative studies greatly outnumber qualitative studies, and that most research takes place in long term care settings. Instruments which measure neuro-psychiatric symptoms of dementia, especially agitation, were the most frequently used. Other domains that were targeted by the studies included quality of life, physiological change, music-related outcomes and cognitive skills; the inter-relations between these domains are represented as a diagram. Researchers' rationales for choosing to target these outcomes are discussed. The conclusion suggests that, although reduction of neuropsychiatric symptoms is a valuable outcome, it is important that researchers are open to the possibility of other outcomes. We suggest that measuring increase in positive responses might be an alternative to measuring reduction of negative symptoms, and highlight the importance of listening to people with dementia and carers when designing studies.
\end{abstract}

\section{Keywords}

Dementia, music, music therapy, outcome measurement, meta-narrative review

\section{Funding}

This work was supported by funding from the Alzheimer's Society (grant number Ref: 225 (AS-DTC-2014-031)) and was carried out as part of a collaborative project of the University of Nottingham and the University of Worcester.

\section{Introduction}

The value of music to people with dementia is widely acknowledged [1,2]. However, research into music and dementia is still a relatively new and developing field, and appears to have evolved fairly independently within different disciplines such as music therapy, psychology and nursing. Systematic reviews synthesise evidence about the effects of music, but tend to focus on one type of intervention or outcome variable, such as music therapy [3] or anxiety [4], and include only certain types of studies [5]. This review takes a broader view and systematically surveys a range of music and dementia studies from different disciplines and across a wide time period.

This paper has been developed from the initial findings of a meta-narrative review of research on music and dementia. Meta-narrative review [6] is founded on Kuhn's [7] idea that science evolves in paradigms which are field-specific. Researchers develop "rules and standards 
which are considered self-evident by those working in a particular field, but which are not universally accepted" [6]. According to Kuhn's theory, scientific paradigms differ in four main realms: the conceptual frameworks through which importance is assigned to certain objects of study, the theoretical dimension which is constructed to explain relationships between variables, the methodological approaches used to investigate, and the instruments which are accepted as appropriate tools for measurement [7]. The approach taken in this review places Kuhn's fourth “domain”: the instruments which are accepted as tools for measurement at the centre of its inquiries.

The "tools for measurement" in this review are the outcome measures, observations and qualitative methods used to assess the impact of music upon people with dementia, which we have collectively termed "indicators". In focusing on the indicators which have been chosen by researchers, the review highlights not the findings of the studies but the ontological and epistemological positions underlying research in this area. It is hypothesised that researchers from different fields may have different conceptual frameworks for the impact of music interventions upon people with dementia, and that these differences are reflected in their choices of indicators. In reviewing the indicators chosen by researchers from different fields, the aim is to gain insight into the outcomes which have been considered important within the various paradigms.

\section{Aims}

The aim of this paper is to provide the reader with a detailed picture of quantitative and qualitative indicators used in studies of music and dementia published since 1980, including important contextual data about study design, sample size, types of dementia and where music interventions take place. We then offer an interpretation of the results which presents the areas of interest for researchers in this field as a set of inter-related domains.

\section{Methods}

Electronic searches were performed in the databases PsychINFO, Medline, CINAHL, EMBASE and Web of Science using variations on the following search strategy, adapted for each database:

\section{1 exp DEMENTIA/}

2 (dement* OR alzheimer*).ti,ab.

3 ("nursing home*" OR "care home*" OR hospice OR hospital*).ti,ab.

4 \#1 OR \#2 OR \#3

$5 \exp$ MUSIC/

6 exp MUSIC THERAPY/

7 (music* OR sing OR sings OR singing OR singer* OR song* OR choir* OR choral* OR playlist* OR listen* OR GIM).ti,ab.

8 (guided imagery adj3 music).ti,ab.

9 ((play* OR learn*) adj3 instrument*).ti,ab.

10 \#5 OR \#6 OR \#7 OR \#8 OR \#9

11 \#4 AND \#10

Music therapy journals were hand-searched for relevant papers. Where systematic reviews were returned by the electronic searches, their reference lists were checked for additional papers. 
Articles written in English and published in peer-reviewed journals between 1980 and March 2018 were considered for inclusion. Broad inclusion criteria were used with the aim of capturing as many different types of research as possible. Studies had to involve research with people with dementia and use live or recorded music intervention with the stated goal of promoting health and/or wellbeing. Studies were included if they used a music alongside another intervention, but only if it was possible to distinguish the results of the musical component. Where studies included both participants with and without dementia, these were included if the results for participants with dementia could be separated from the other results. Other types of articles were excluded (e.g. conference proceedings, editorials) as were articles where it was not clear which participants had dementia, or where the study combined music with another activity (e.g. dance accompanied by music).

Data including type of music intervention, study setting and methodology, outcome measures used, and details about the study sample, was extracted from each paper and tabulated. Quality assessment of the studies was not performed; since the review focuses on the indicators selected by researchers rather than the actual findings, it was considered relevant to include studies of varying methodological quality.

\section{Results}

\section{Characteristics of the data}

Figure 1: PRISMA flow chart

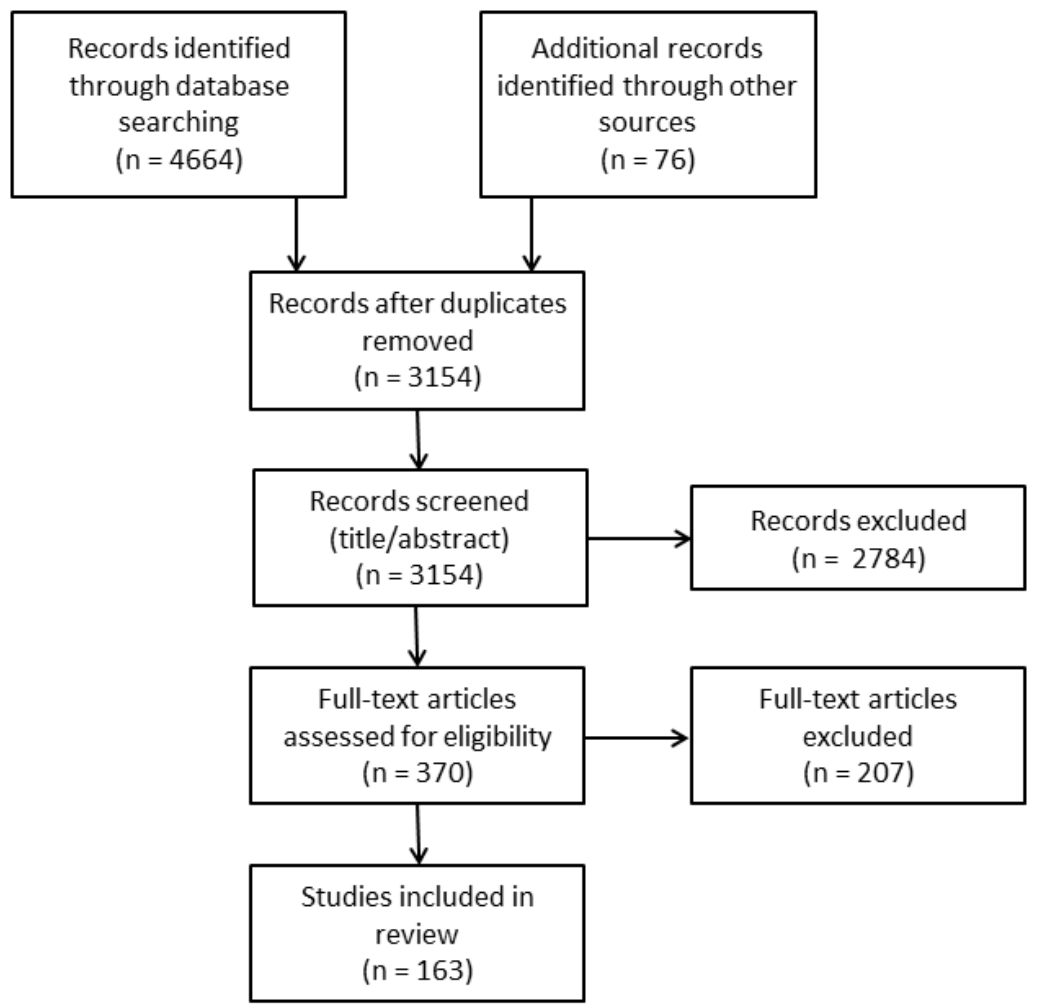

Figure 1 shows the flow of articles through the review process. After screening papers at title and abstract level, 2784 articles were excluded. Full texts were screened for the remaining articles andas a result of this process, 163 papers were included in the review. These 
represent the findings of 154 studies, since some studies reported their findings in multiple papers. The chronology of studies included in this review clearly represents an expanding field of research; more papers have been published from 2010 onwards than in the preceding thirty years. The majority of studies included in this review $(83 \%)$ used quantitative methodology, while $7 \%$ of studies were qualitative and a further $7 \%$ used a mixed methods approach. Two case studies were included (1\%) while the remaining $2 \%$ of studies were categorised as "multi methods" meaning that they used some qualitative and quantitative methods, but did not integrate them. Table 1 shows a summary of the study designs included in these papers .

Table 1: Study methodology and design

\begin{tabular}{|l|l|l|l|}
\hline Methodology & Study design & $\begin{array}{l}\text { No. of } \\
\text { studies }\end{array}$ & $\begin{array}{l}\text { Sample size - mean, } \\
\text { median (range) }\end{array}$ \\
\hline Quantitative & Randomised Controlled Study & 28 & $35.4,24.5(15-120)$ \\
\hline & Controlled study & 20 & $37,27.5(10-80)$ \\
\hline & Other & 80 & $33.6,20(1-212)$ \\
\hline Qualitative & & 12 & $25.8,24(6-62)$ \\
\hline Mixed methods & & 9 & $16,11(5-29)$ \\
\hline Case study & & 2 & $1.5,1.5(1-2)$ \\
\hline Multi methods & & 3 & $13,10(7-22)$ \\
\hline
\end{tabular}

A total of 101 studies took place in long-term residential care settings, with community settings ( 21 studies) and hospitals (10 studies) being the next most common contexts for studies. The remaining studies took place in domestic settings, day centres, dementia centres, or universities. 13 studies took place in more than one type of setting, and 11 studies did not state where they took place.

Studies were categorised by the type(s) of music intervention or activity they employed. The interventions included music therapy, defined as a psychological clinical intervention delivered by therapists who have met the standards of professional training and regulation in their country of practice. Other activities, such as listening to recorded or live music, and singing might be delivered by music therapists, care staff, community musicians, or family carers. Listening to recorded music was the most frequent activity, with 70 studies employing this in some form. 55 studies involved music therapy, representing an established research tradition. Twelve studies involved singing; the other categories are populated by small numbers of studies.

The types of dementia experienced by the participants in the studies are somewhat variably reported. 38\% of studies stated that participants all had diagnosed or probable Alzheimer's disease, whilst $23 \%$ reported a mixture of different types of dementia. Two studies focused exclusively on fronto-temporal dementia, and one on three different but specified types (Alzheimer's, vascular dementia and Parkinson's dementia) but the remaining 40\% did not report the type of dementia at all. This may be because study authors felt that the severity of dementia was more relevant than the type, due to the difficulty of conclusive diagnosis and the prevalence of mixed dementia. Dementia severity was frequently reported, either by describing it as mild, moderate or severe, or through mean/standard deviation and range of MMSE scores. 


\section{Quantitative outcome measures}

Table 2 shows all the standardised quantitative outcome measures which were used more than once in the included studies, the domain to which they relate, and the number of times that each was used. They are arranged in descending order of frequency. The CohenMansfield Agitation Inventory, Mini-Mental State Examination and Neuro-Psychiatric Inventory were used more than ten times each, while the next most frequently used measures (Rating Anxiety in Dementia) was used only five times. A further 60 standardised outcome measures were used once each, while a number of other studies used outcome measures created specifically for that study.

Table 2: Frequency of standardised outcome measures

\begin{tabular}{|c|c|c|}
\hline Outcome Measure & Relates to domain & Frequency \\
\hline Cohen-Mansfield Agitation Inventory & Agitation & 31 \\
\hline Mini-Mental State Examination & Cognitive function & 16 \\
\hline Neuro-Psychiatric Inventory & $\begin{array}{l}\text { Neuropsychiatric dementia } \\
\text { symptoms }\end{array}$ & 12 \\
\hline $\begin{array}{l}\text { Cornell Scale for Depression in } \\
\text { Dementia }\end{array}$ & Depression & 6 \\
\hline Dementia Care Mapping & Quality of life & 5 \\
\hline Rating Anxiety in Dementia & Anxiety & 5 \\
\hline Geriatric Depression Scale & Depression & 4 \\
\hline Barthel Index & Activities of Daily Living & 3 \\
\hline $\begin{array}{l}\text { Behavioral Pathology in Alzheimer's } \\
\text { Disease Rating Scale }\end{array}$ & Behaviour & 3 \\
\hline Observed Emotion Rating Scale & Mood & 3 \\
\hline Quality of Life - Alzheimer's Disease & Quality of life & 3 \\
\hline Test épisodique de mémoire du passé & Memory & 3 \\
\hline $\begin{array}{l}\text { Bedford Alzheimer Nursing Severity } \\
\text { Scale }\end{array}$ & Dementia severity & 2 \\
\hline $\begin{array}{l}\text { Cornell-Brown Scale for Quality of } \\
\text { Life in Dementia }\end{array}$ & Quality of Life & 2 \\
\hline Disruptive Behaviour Rating Scale & Behaviour & 2 \\
\hline Lawton's Modified Behaviour Stream & Mood & 2 \\
\hline $\begin{array}{l}\text { Montgomery-Åsberg Depression } \\
\text { Rating Scale }\end{array}$ & Depression & 2 \\
\hline Music in Dementia Assessment Scale & Musical engagement & 2 \\
\hline Menorah park engagement scale & Engagement & 2 \\
\hline Paper Folding and Cutting & Cognitive function & 2 \\
\hline State-Trait Anxiety Inventory & Anxiety & 2 \\
\hline
\end{tabular}

\section{Qualitative methods}

11 studies (reported in 16 papers) used purely qualitative methods. The most commonly used methods were interviews either with caregivers and people with dementia or with caregivers alone, and qualitative analysis of video or audio material. Another 14 studies integrated qualitative methods as part of a mixed methods approach. Some of these studies investigate the pilot stage of novel interventions [8-10] or the development of new technology prototypes [11-13]. In these cases, the qualitative data provides information about participants' experience which can be integrated into the development. 
Several studies have as their focus the development of theories or models which can explain the value of music to people with dementia, and consequently represent in-depth inquiries into musical experiences [14-16]. Six papers report qualitative findings from the same investigation into the effects of "music therapeutic caregiving" (caregiver singing during personal care situations); among these were qualitative content analysis of interview transcripts explored the caregivers' own experiences [17] and their perception of the experiences of people with dementia [18].

\section{Discussion}

Within the developing field of research into music and dementia, a wide range of measures and methods have been employed. In order to summarise and explore the data, the standardised and study-specific outcome measures used in the studies were each assigned to a domain representing the variable which they measure. These domains were then reviewed and grouped together into five broader categories: neuropsychiatric symptoms, quality of life, cognitive function, physiological changes and music-related response. Figure 2 is a graphical representation of the categories and the links between domains within and across them, showing the most common domains for each category. There are clear links between categories; for example, reduction in symptoms of depression can be associated with improvement in mood. Additionally, the domain "behaviour" can be placed in either the "quality of life" or "neuropsychiatric symptoms" category, depending on whether a study is focusing on reduction of so-called "negative" behaviours (e.g. aggression, shouting) or increased in "positive" behaviours (e.g. communication, interaction). 


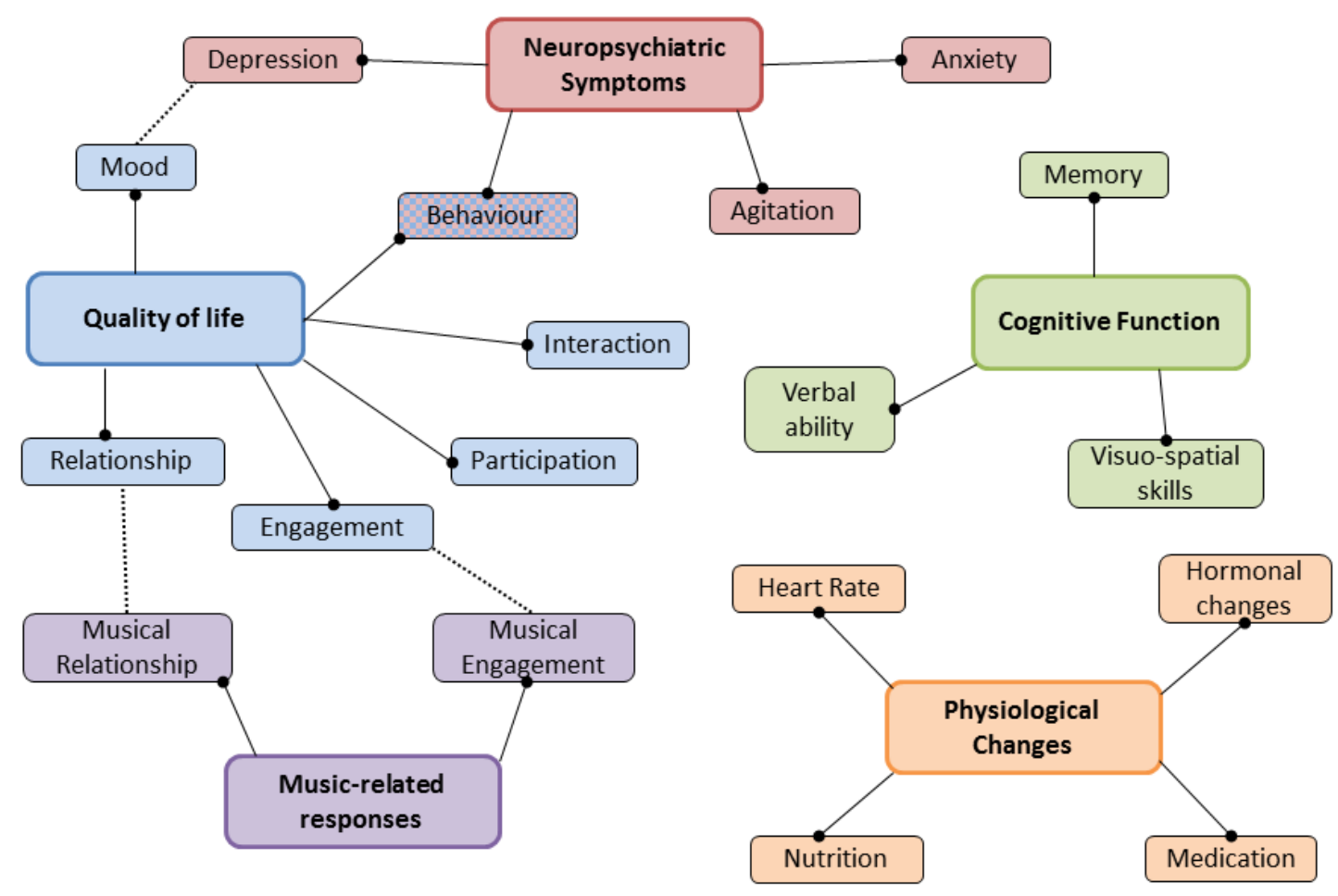

In the following section, the full texts of studies which used quantitative outcome measures for each of the five domains are examined, in order to explore the underlying theoretical and methodological assumptions which guide the choice of instrument.

\section{Neuropsychiatric Symptoms}

71 studies $[9,19-88]$ used quantitative outcome measures to evaluate various neuropsychiatric symptoms of dementia. Of these, 58 took place in residential care settings, suggesting that the reduction of neuropsychiatric symptoms is considered to be of great importance in this context. 37 studies measured agitation, 32 of these using the CohenMansfield Agitation Inventory (CMAI). The extensive prioritisation of agitation is perhaps explained by the burden it places on caregivers, and the fact that decrease in agitated behaviours is fairly straightforward to observe and measure using standard tools. Many studies cite caregiver burden [58] or the need to develop nonpharmacological interventions [89] as their reason for targeting neuropsychiatric symptoms of dementia. In other studies, decrease in neuropsychiatric symptoms is correlated with improvement in quality of life, both for people with dementia and their caregivers [49].

\section{Quality of life/Wellbeing}

28 studies were categorised only in the "quality of life" domain [90-117], while a further 22 include quality of life among other measures $[9,21,26,27,30,38,46,50,55,60,61,67,71,76,87,118-125]$. Studies measuring quality of life in the 1990s are often associated with music therapy; later, other types of intervention appear as well. Music therapy research in the 1990s and early 2000s tended not to use standardised quality of life scales, but instead created study-specific behavioural inventories. For example, 
Pollack and Namazi [106] designed a checklist to record the frequency of social and nonsocial behaviours of participants, while Clair and Bernstein [20] measured the duration of specific responses such as singing, communicating and interacting with a musical instrument. In these papers, music is hypothesized to promote social engagement and purposeful activity which may be compromised by cognitive impairment.

Many later papers use standardised outcome measures but similarly cite music's potential to engage cognitively impaired and under-stimulated individuals in meaningful activity, especially by providing a means for making social contact with others $[93,94,126]$. Several studies draw an explicit link between boredom resulting from lack of stimulation, and disruptive behaviour [91,93]. The phrase "promoting wellness" is used in one study [127], whereas many of the others seem to explicitly link quality of life with the absence of behavioural and psychiatric symptoms. This raises questions about whether quality of life is represented by the presence of a positive state of being, or whether it is simply the absence of negative symptoms which detract from wellbeing. It is also worth noting that later studies include ratings of QoL which are given directly by people with dementia, rather than through observation or proxy $[120,124]$.

\section{Cognitive Function}

18 studies [128-145] focused exclusively on the quantitative measurement of aspects of cognitive function, including different types of memory, visuospatial and language skills, and overall cognitive performance using measures such as the Mini-Mental State Examination. From these studies, three mechanisms can be identified through which enhanced cognition resulting from musical stimuli may be associated with positive outcomes for people with dementia. Firstly, a decrease in neuropsychiatric symptoms brought about by music is postulated to have a positive effect on cognitive function [146]. Secondly, music as a memory enhancer has practical applications for improving performance of activities of daily living which may enhance quality of life [147]. Thirdly, music may be used to preserve autobiographical memories and maintain sense of identity, which also has implications for quality of life $[131,140]$.

\section{Physiological Changes}

Eleven studies measure only physiological variables [148-158]. Four of these focused on nutrition, one on brain activity, three on aspects of motor functioning and two on hormone levels. A further ten studies include measurement of a physiological variable alongside other measures, commonly of neuropsychiatric symptoms. In several cases an explicit link is drawn between reduction of neuropsychiatric symptoms and a favourable physiological outcome. For example, Gill \& Englert [151] link agitation levels in people with dementia to an increased risk of falls, so music is explored as a means of reducing agitation and therefore reducing falls. The studies which focus on nutrition draw similar links; they hypothesise that playing background music at mealtimes could improve the environment and decrease stress and anxiety $[150,154,157]$. Clair and O'Konski [148] explore Rhythmic Auditory Cueing (RAC) to improve gait, linking falls and decreased mobility resulting from unsafe walking to decreases in physical health and quality of life.

\section{Music-related outcomes}

Seven studies used music-related quantitative outcome measures, generally to support the evidence provided by other outcome measures, or to explain the mechanisms by which such outcomes occur [52,60,82,85,122,159-161]. Ceccato et al. [85] used rating scales for evaluating musical competencies and relationship. They predicted that if the musical relationship improved, a decrease in neuropsychiatric symptoms would be noted. Similarly, 
Raglio et al. [60] assessed change in the musical communication of a subset of patients involved in a larger trial which was primarily investigating neuropsychiatric symptoms.

Two papers $[122,162]$ report stages in the development of a tool to address the "lack of client-specific, clinically appropriate, and psychometrically evaluated outcome measures" in music therapy [122]. The resulting measure, the Music in Dementia Assessment Scale, is intended to capture change which is individual and focused on what matters to the client, rather than just on reducing neuropsychiatric symptoms. In order to develop this scale, interviews and focus groups were conducted with people with dementia, carers and music therapists to discover why music was important to them. Analysis of the data showed that music was seen as an accessible and instantly engaging medium for people at all stages of dementia. It held great personal significance and allowed people to maintain and express their identity, whilst also providing a means for people with dementia to build and sustain relationships. Music also facilitated short-term improvements in mood [15]

\section{Conclusions}

The findings of this review indicate that certain outcomes, in particular reduction of neuropsychiatric symptoms, have been prioritised in music and dementia research, perhaps to the exclusion of other areas. These areas include positive responses such as music's potential to support and strengthen relationships, provide "in the moment" experiences, and meet the psychosocial needs of people with dementia. This priority is understandable in light of the fact that neuropsychiatric symptoms of dementia are reported to cause more distress and burden to people with dementia and their caregivers than cognitive symptoms of dementia and results in early care home placement, increased hospital admissions, and lower quality of life for people with dementia and caregivers [163]. However, we risk ignoring part of the spectrum of benefits that music can have if we focus predominantly on symptom reduction. It may be that we need to broaden our horizons and ask more searching questions about the kinds of outcomes we look for, and some progress has already been made. Vink et al. [83] noted that the effect of music therapy on positive responses for people with dementia has been under-researched, and Music in Dementia Assessment Scales (MiDAS) were developed "to capture some of the aspects of musical experiences that people with dementia themselves would say are meaningful to measure" [122]. The items included in MiDAS were based on consultation with people with dementia and their carers about what music meant for them. The scale itself employs ratings judged by someone who knows the person with dementia well, allowing them to assess responses to music therapy according to each individual's potential levels. Investigating positive responses may also improve understanding of the mechanisms involved in the complexities of human reaction to music.

The view that our perception of dementia has been hampered by a medical model is not new; as long ago as 1992, Cotrell and Shulz wrote that "our understanding of AD has become increasingly biomedical, with an accompanying tendency to attribute the experience of persons with dementia exclusively to a disease process" [164]. This perspective may explain the propensity to see music as a treatment which can be applied to people with dementia in much the same way as a drug, albeit one with fewer side effects. However, this reductive approach neglects the complex power of music across human societies and in our daily lives; Tia DeNora has written that music is not a "stimulus"; it does not in its essence contain all the qualities necessary to regulate someone's mood, for example. Rather, "music's powers are constituted by [the listener] herself; they derive from the ways she interacts with them" [165]. People with dementia must be considered to experience music in the same rich, complex and variable way, mediated by their experiences, memories and personalities. This assertion is 
supported by qualitative research into the meaning of music for people with dementia $[14,166]$.

We must listen to the perspectives of people with dementia when designing research, and ensure that the outcome variables chosen reflect changes which they acknowledge as valuable and relevant. This is an under-researched area but some important work has already been done. McDermott et al. suggest that the importance of music to people with dementia "goes beyond the idea of music as a tool to fix a behavioural problem (e.g. agitation) suggesting that it is part of a wider appreciation of life" [15]. People with dementia and their carers suggest that the key characteristics of music for them are that it facilitates social interaction, helps to maintain relationships, reinforces their sense of identity, remains meaningful and accessible through all stages of dementia, and that overall it supports the wellbeing of both people with dementia and those involved in their care $[14,15,167]$. It is probable that these positive outcomes have been neglected in quantitative research because they are considered more difficult to measure than outcomes which can be based on behavioural or symptomatic inventories. Before the development of any new outcome measures, further in-depth qualitative research involving consultation with people with dementia and their carers should be carried out to broaden our understanding of the mechanisms through which music can bring about change. To facilitate this, there is a need to adapt research so that it can include people with dementia, rather than excluding people with dementia from research because they cannot access the conventional methods [168]. Furthermore, we must take on board criticisms of established practice, such as dementia activist Kate Swaffer's campaign against the term "Behavioural and Psychological Symptoms of Dementia" on the grounds that it dehumanises people with dementia and contributes to poor care by reducing them to a set of "challenging behaviours", rather than seeing these behaviours as responses to unmet needs [169].

The process involved in choosing outcome measures is not self-evident, and reflects the values and underlying theoretical frameworks of the researchers. It is hoped that this review will encourage researchers in this new and developing field to use and develop methods which are relevant to clinicians, practitioners, carers - and to people with dementia themselves.

\section{References}

[1] All Party Parliamentary Group on Arts Health and Wellbeing, Creative health: The arts for health and wellbeing, London, 2017.

https://www.artshealthandwellbeing.org.uk/appginquiry/Publications/Creative_Health_Inquiry_Report_2017_-_Second_Edition.pdf.

[2] The Commission on Dementia and Music, "What would life be - without a song or a dance, what are we?": A report from the commission on dementia and music, 2018. http://www.ilcuk.org.uk/index.php/publications/publication_details/what_would_life_ be_without_a_song_or_dance_what_are_we.

[3] Y.-S. Chang, H. Chu, C.-Y. Yang, J.-C. Tsai, M.-H. Chung, Y.-M. Liao, M. Chi, M.F. Liu, K.-R. Chou, The efficacy of music therapy for people with dementia: A metaanalysis of randomised controlled trials., J. Clin. Nurs. 24 (2015) 3425-3440. doi:10.1111/jocn.12976.

[4] D. Petrovsky, P.Z. Cacchione, M. George, Review of the effect of music interventions 
on symptoms of anxiety and depression in older adults with mild dementia, Int. Psychogeriatrics. 27 (2015) 1661-1670. doi:10.1017/S1041610215000393.

[5] J. van Der Steen, H. Smaling, J. Van Der Wouden, M. Bruinsma, R. Scholten, A. Vink, Music-based therapeutic interventions for people with dementia ( Review ), Cochrane Database Syst. Rev. (2018) 1-86. doi:10.1002/14651858.CD003477.pub3.

[6] T. Greenhalgh, G. Robert, F. MacFarlane, P. Bate, O. Kyriakidou, R. Peacock, Storylines of research in diffusion of innovation: A meta-narrative approach to systematic review, Soc. Sci. Med. 61 (2005) 417-430.

doi:10.1016/j.socscimed.2004.12.001.

[7] T.S. Kuhn, The Structure of Scientific Revolutions, University of Chicago Press, Chicago, 1962. doi:10.1046/j.1440-1614.2002.t01-5-01102a.x.

[8] N. Bannan, C. Montgomery-Smith, 'Singing for the Brain': reflections on the human capacity for music arising from a pilot study of group singing with Alzheimer's patients, J. R. Soc. Promot. Health. 128 (2008) 73-78. doi:10.1177/1466424007087807.

[9] P.M. Camic, C.M. Williams, F. Meeten, Does a "Singing Together Group" improve the quality of life of people with a dementia and their carers? A pilot evaluation study., Dementia. 12 (2011) 157-176. doi:10.1177/1471301211422761.

[10] P.B. Harris, C.A. Caporella, An intergenerational choir formed to lessen Alzheimer's disease stigma in college students and decrease the social isolation of people with Alzheimer's disease and their family members: a pilot study., Am. J. Alzheimers. Dis. Other Demen. 29 (2014) 270-281.

http://ovidsp.ovid.com/ovidweb.cgi?T=JS\&PAGE=reference $\& D=$ medl\&NEWS=N\& AN $=24413542$.

[11] M.M.M. Peeters, M. Harbers, M.A. Neerincx, Designing a personal music assistant that enhances the social, cognitive, and affective experiences of people with dementia, Comput. Human Behav. 63 (2016) 727-737. doi:10.1016/j.chb.2016.06.003.

[12] P. Riley, N. Alm, A. Newell, An interactive tool to promote musical creativity in people with dementia., Comput. Human Behav. 25 (2009) 599-608.

http://ovidsp.ovid.com/ovidweb.cgi?T=JS\&PAGE=reference $\& D=$ psyc6\&NEWS=N\& $\mathrm{AN}=2009-06406-003$.

[13] P. Topo, O. Maki, K. Saarikalle, N. Clarke, E. Begley, S. Cahill, J. Arenlind, T. Holthe, H. Morbey, K. Hayes, J. Gilliard, Assessment of a music-based multimedia program for people with dementia., Dement. Int. J. Soc. Res. Pract. 3 (2004) 331-350. http://ovidsp.ovid.com/ovidweb.cgi?T=JS\&PAGE=reference $\& D=$ psyc4\&NEWS=N\& AN=2004-20807-006.

[14] A. Sixsmith, G. Gibson, Music and the wellbeing of people with dementia., Ageing Soc. 27 (2007) 127-145.

http://ovidsp.ovid.com/ovidweb.cgi?T=JS\&PAGE=reference $\& D=p s y c 5 \& N E W S=N \&$ AN=2007-03276-007.

[15] O. McDermott, M. Orrell, H.M. Ridder, M. O., O. M., The importance of music for people with dementia: the perspectives of people with dementia, family carers, staff and music therapists, Aging Ment. Health. 18 (2014) 706-716. doi:10.1080/13607863.2013.875124.

[16] S.. Osman, V. Tischler, J. Schneider, Singing for the Brain: A qualitative study exploring the health and well-being benefits of singing for people with dementia and their carers, Dementia. 15 (2014) 1326-1339. doi:10.1177/1471301214556291.

[17] L.M. Hammar, A. Emami, G. Engström, E. Götell, Finding the key to communionCaregivers" experience of "music therapeutic caregiving" in dementia care: A qualitative analysis., Dement. Int. J. Soc. Res. Pract. 10 (2011) 98-111. 
http://ovidsp.ovid.com/ovidweb.cgi?T=JS\&PAGE=reference $\& D=p s y c 8 \& N E W S=N \&$ AN=2014-10994-007.

[18] L.M. Hammar, A. Emami, G. Engström, E. Götell, Reactions of Persons with Dementia to Caregivers Singing in Morning Care Situations., Open Nurs. J. 4 (2010) 34-41. http://search.ebscohost.com/login.aspx ?direct=true \&db=rzh\&AN=104510382\&site=e host-live.

[19] S. Ashida, The effect of reminiscence music therapy sessions on changes in depressive symptoms in elderly persons with dementia, J. Music Ther. 37 (2000) 170-182.

http://ovidsp.ovid.com/ovidweb.cgi?T=JS\&PAGE=reference $\& D=$ med4\&NEWS=N\& $\mathrm{AN}=10990595$.

[20] A.A. Clair, B. Bernstein, The effect of no music, stimulative background music and sedative background music on agitated behaviors in persons with severe dementia., Act. Adapt. Aging. 19 (1994) 61-70.

http://search.ebscohost.com/login.aspx?direct=true\&db=rzh\&AN=107392410\&site=e host-live.

[21] A.A. Clair, A. Ebberts, The effects of music therapy on interactions between family caregivers and their care receivers with late stage dementia., J. Music Ther. 34 (1997) $148-164$.

http://ovidsp.ovid.com/ovidweb.cgi?T=JS\&PAGE=reference $\& D=p s y c 3 \& N E W S=N \&$ $\mathrm{AN}=1997-41284-001$.

[22] K.A. Clarkson, K.-L. Cassidy, G.A. Eskes, Singing soothes: Music concerts for the management of agitation in older adults with dementia, Can. J. Geriatr. 10 (2007) 8087.

http://ovidsp.ovid.com/ovidweb.cgi?T=JS\&PAGE=reference\&D=emed11\&NEWS=N $\& \mathrm{AN}=350004657$.

[23] S. Clement, A. Tonini, F. Khatir, L. Schiaratura, S. Samsony, Short and longer term effects of musical intervention in severe Alzheimer's disease., Music Percept. 29 (2012) 533-541.

http://ovidsp.ovid.com/ovidweb.cgi?T=JS\&PAGE=reference \&D=psyc9\&NEWS=N\& $\mathrm{AN}=2012-15378-008$.

[24] J. Cohen-Mansfield, P. Werner, Management of verbally disruptive behaviors in nursing home residents, J. Gerontol. A. Biol. Sci. Med. Sci. 52 (1997) M369-M377. http://ovidsp.ovid.com/ovidweb.cgi?T=JS\&PAGE=reference $\& D=$ med4\&NEWS=N\& $\mathrm{AN}=9402944$.

[25] J. Cohen-Mansfield, M.S. Marx, M. Dakheel-Ali, N.G. Regier, K. Thein, L. Freedman, Can agitated behavior of nursing home residents with dementia be prevented with the use of standardized stimuli?, J. Am. Geriatr. Soc. 58 (2010) 1459-1464. http://ovidsp.ovid.com/ovidweb.cgi?T=JS\&PAGE=reference $\& D=$ med6\&NEWS=N\& $\mathrm{AN}=20579167$.

[26] J. Cohen-Mansfield, M.S. Marx, M. Dakheel-Ali, K. Thein, The use and utility of specific nonpharmacological interventions for behavioral symptoms in dementia: An exploratory study, Am. J. Geriatr. Psychiatry. 23 (2015) 160-170. http://www.sciencedirect.com/science/journal/10647481.

[27] J. Cohen-Mansfield, M.S. Marx, K. Thein, M. Dakheel-Ali, The impact of past and present preferences on stimulus engagement in nursing home residents with dementia., Aging Ment. Health. 14 (2010) 67-73. http://ovidsp.ovid.com/ovidweb.cgi?T=JS\&PAGE=reference $\& D=$ emed12\&NEWS=N \&AN=358761995.

[28] M.L. Cooke, W. Moyle, D.H.K. Shum, S.D. Harrison, J.E. Murfield, A randomized 
controlled trial exploring the effect of music on agitated behaviours and anxiety in older people with dementia., Aging Ment. Health. 14 (2010) 905-916.

http://ovidsp.ovid.com/ovidweb.cgi?T=JS\&PAGE=reference $\& D=$ med6\&NEWS=N\& AN=20635236.

[29] E. Cox, M. Nowak, P. Buettner, Managing agitated behaviour in people with Alzheimer's disease: The role of live music., Br. J. Occup. Ther. 74 (2011) 517-524. http://ovidsp.ovid.com/ovidweb.cgi?T=JS\&PAGE=reference $\& D=p s y c 8 \& N E W S=N \&$ $\mathrm{AN}=2011-28003-003$.

[30] F.A. Baker, D. Grocke, N.A. Pachana, Connecting through music: A study of a spousal caregiver-directed music intervention designed to prolong fulfilling relationships in couples where one person has dementia., Aust. J. Music Ther. 23 (2012) 4-19. http://ovidsp.ovid.com/ovidweb.cgi?T=JS\&PAGE=reference $\& D=$ psyc9\&NEWS=N\& $\mathrm{AN}=2012-27692-001$.

[31] E. Cox, M. Nowak, P. Buettner, Live music promotes positive behaviours in people with Alzheimer's disease., Br. J. Occup. Ther. 77 (2014) 556-564.

http://ovidsp.ovid.com/ovidweb.cgi?T=JS\&PAGE=reference $\& D=$ psyc11\&NEWS $=\mathrm{N}$ \&AN=2015-13053-006.

[32] J.C. Gardiner, M. Furois, D.P. Tansley, B. Morgan, Music therapy and reading as intervention strategies for disruptive behavior in dementia., Clin. Gerontol. J. Aging Ment. Heal. 22 (2000) 31-46.

http://ovidsp.ovid.com/ovidweb.cgi?T=JS\&PAGE=reference $\& D=p s y c 3 \& N E W S=N \&$ $\mathrm{AN}=2001-16221-003$.

[33] L. Gerdner, An individualized music intervention for agitation., J. Am. Psychiatr. Nurses Assoc. 3 (1997) 177-184.

http://search.ebscohost.com/login.aspx?direct=true \&db=rzh\&AN=107246247\&site=e host-live.

[34] L.A. Gerdner, Effects of individualized versus classical "relaxation" music on the frequency of agitation in elderly persons with Alzheimer's disease and related disorders., Int. Psychogeriatrics. 12 (2000) 49-65.

http://ovidsp.ovid.com/ovidweb.cgi?T=JS\&PAGE=reference $\& D=e m e d 8 \& N E W S=N \&$ $\mathrm{AN}=30180714$.

[35] L.A. Gerdner, Use of individualized music by trained staff and family: translating research into practice, J. Gerontol. Nurs. 31 (2005) 22-26.

http://ovidsp.ovid.com/ovidweb.cgi?T=JS\&PAGE=reference $\& D=e m e d 10 \& N E W S=N$ \&AN=41590027.

[36] L.A. Gerdner, E.A. Swanson, Effects of individualized music on confused and agitated elderly patients., Arch. Psychiatr. Nurs. 7 (1993) 284-291.

http://ovidsp.ovid.com/ovidweb.cgi?T=JS\&PAGE=reference $\& D=e m e d 6 \& N E W S=N \&$ $\mathrm{AN}=24848407$.

[37] J. Goddaer, I.L. Abraham, Effects of relaxing music on agitation during meals among nursing home residents with severe cognitive impairment, Arch. Psychiatr. Nurs. 8 (1994) 150-158.

http://ovidsp.ovid.com/ovidweb.cgi?T=JS\&PAGE=reference $\& D=\operatorname{med} 3 \& N E W S=N \&$ $\mathrm{AN}=8080303$.

[38] K. Gold, But does it do any good? Measuring the impact of music therapy on people with advanced dementia: (Innovative practice)., Dementia. 13 (2014) 258-264.

http://ovidsp.ovid.com/ovidweb.cgi?T=JS\&PAGE=reference $\& D=$ medl\&NEWS=N\& $\mathrm{AN}=24339096$.

[39] S. Guetin, F. Portet, M.-C. Picot, C. Pommie, M. Messaoudi, L. Djabelkir, A.L. Olsen, M.M. Cano, E. Lecourt, J. Touchon, Effect of music therapy on anxiety and depression 
in patients with Alzheimer's type dementia: randomised, controlled study., Dement. Geriatr. Cogn. Disord. 28 (2009) 36-46. doi:10.1159/000229024.

[40] L.M. Hammar, A. Emami, E. Götell, G. Engström, The impact of caregivers' singing on expressions of emotion and resistance during morning care situations in persons with dementia: An intervention in dementia care, J. Clin. Nurs. 20 (2011) 969-978. http://ovidsp.ovid.com/ovidweb.cgi?T=JS\&PAGE=reference $\& D=$ med7\&NEWS=N\& $\mathrm{AN}=21309873$.

[41] C. Ballard, R. Brown, J. Fossey, S. Douglas, P. Bradley, J. Hancock, I. James, E. Juszczak, P. Bentham, A. Burns, J. Lindesay, R. Jacoby, J. O’Brien, R. Bullock, T. Johnson, C. Holmes, R. Howard, Brief psychosocial therapy for the treatment of agitation in Alzheimer disease (The CALM-AD trial), Am. J. Geriatr. Psychiatry. 17 (2009) 726-733.

http://ovidsp.ovid.com/ovidweb.cgi?T=JS\&PAGE=reference $\& D=$ med6\&NEWS=N\& $\mathrm{AN}=19700946$.

[42] E. Helmes, D.C. Wiancko, Effects of Music in Reducing Disruptive Behavior in a General Hospital., J. Am. Psychiatr. Nurses Assoc. 12 (2006) 37-44.

http://ovidsp.ovid.com/ovidweb.cgi?T=JS\&PAGE=reference $\& D=p s y c 5 \& N E W S=N \&$ $\mathrm{AN}=2006-08841-006$.

[43] S.L. Hicks-Moore, B.A. Robinson, Favorite music and hand massage: Two interventions to decrease agitation in residents with dementia., Dement. Int. J. Soc. Res. Pract. 7 (2008) 95-108.

http://ovidsp.ovid.com/ovidweb.cgi?T=JS\&PAGE=reference $\& D=$ psyc6\&NEWS=N\& AN=2008-01605-006.

[44] S.L. Hicks-Moore, Relaxing music at mealtime in nursing homes: effects on agitated patients with dementia, J. Gerontol. Nurs. 31 (2005) 26-32.

http://ovidsp.ovid.com/ovidweb.cgi?T=JS\&PAGE=reference $\& D=$ med5\&NEWS=N\& $\mathrm{AN}=16375095$.

[45] S.-Y. Ho, H.-L. Lai, S.-Y. Jeng, C.-W. Tang, H.-C. Sung, P.-W. Chen, The Effects of Researcher-Composed Music at Mealtime on Agitation in Nursing Home Residents With Dementia, Arch. Psychiatr. Nurs. 25 (2011) e49-e55. http://ovidsp.ovid.com/ovidweb.cgi?T=JS\&PAGE=reference $\& D=$ emed13\&NEWS $=\mathrm{N}$ \&AN=362988510.

[46] M.H. Hsu, R. Flowerdew, M. Parker, J.J. Fachner, H. Odell-Miller, Individual music therapy for managing neuropsychiatric symptoms for people with dementia and their carers: a cluster randomised controlled feasibility study., BMC Geriatr. 15 (2015) 84. doi:10.1186/s12877-015-0082-4.

[47] M. lrish, C.J. Cunningham, J.B. Walsh, D. Coakley, B.A. Lawlor, I.H. Robertson, R.F. Coen, Investigating the enhancing effect of music on autobiographical memory in mild Alzheimer's disease, Dement. Geriatr. Cogn. Disord. 22 (2006) 108-120. http://ovidsp.ovid.com/ovidweb.cgi?T=JS\&PAGE=reference $\& D=$ emed10\&NEWS $=\mathrm{N}$ $\& \mathrm{AN}=43909837$.

[48] B. Jennings, D. Vance, The short-term effects of music therapy on different types of agitation in adults with Alzheimer's., Act. Adapt. Aging. 26 (2002) 27-33. http://ovidsp.ovid.com/ovidweb.cgi?T=JS\&PAGE=reference $\& D=p s y c 4 \& N E W S=N \&$ $\mathrm{AN}=2003-04252-003$.

[49] A.J. Ledger, F.A. Baker, An investigation of long-term effects of group music therapy on agitation levels of people with Alzheimer's disease, Aging Ment. Health. 11 (2007) 330-338. http://search.ebscohost.com/login.aspx?direct=true\&db=rzh\&AN=105917638\&site=e host-live. 
[50] B. Lesta, P. Petocz, Familiar Group Singing: Addressing Mood and Social Behaviour of Residents with Dementia Displaying Sundowning., Aust. J. Music Ther. 17 (2006) $2-17$.

http://ovidsp.ovid.com/ovidweb.cgi?T=JS\&PAGE=reference $\& D=p s y c 5 \& N E W S=N \&$ AN=2006-07972-001.

[51] C.-H. Li, C.-K. Liu, Y.-H. Yang, M.-C. Chou, C.-H. Chen, C.-L. Lai, Adjunct effect of music therapy on cognition in alzheimer's disease in Taiwan: A pilot study,

Neuropsychiatr. Dis. Treat. 11 (2015) 291-296.

http://www.dovepress.com/getfile.php?fileID=23589.

[52] M. Belgrave, The effect of expressive and instrumental touch on the behavior states of older adults with late-stage dementia of the Alzheimer's type and on music therapist's perceived rapport, J. Music Ther. 46 (2009) 132-146.

http://ovidsp.ovid.com/ovidweb.cgi?T=JS\&PAGE=reference $\& D=$ med6\&NEWS=N\& $\mathrm{AN}=19463031$.

[53] Y. Lin, H. Chu, C.Y. Yang, C.H. Chen, S.G. Chen, H.J. Chang, C.J. Hsieh, K.R. Chou, Effectiveness of group music intervention against agitated behavior in elderly persons with dementia, Int. J. Geriatr. Psychiatry. 26 (2011) 670-678. doi:10.1002/gps.2580.

[54] J.M. Locke, O.C. Mudford, Using music to decrease disruptive vocalizations in a man with dementia., Behav. Interv. 25 (2010) 253-260.

http://ovidsp.ovid.com/ovidweb.cgi?T=JS\&PAGE=reference $\& D=$ psyc7\&NEWS=N\& AN=2010-13689-006.

[55] A. Myskja, P.G. Nord, "The day the music died": A pilot study on music and depression in a nursing home., Nord. J. Music Ther. 17 (2008) 30-40.

http://ovidsp.ovid.com/ovidweb.cgi?T=JS\&PAGE=reference $\& D=$ psyc6\&NEWS=N\& $\mathrm{AN}=2008-03738-004$.

[56] B.K. Nair, C. Heim, C. Krishnan, C. D’Este, J. Marley, J. Attia, The effect of Baroque music on behavioural disturbances in patients with dementia, Australas. J. Ageing. 30 (2011) 11-15.

http://ovidsp.ovid.com/ovidweb.cgi?T=JS\&PAGE=reference $\& D=$ med7 $\& N E W S=N \&$ $\mathrm{AN}=21395934$.

[57] S. Samson, S. Clement, P. Narme, L. Schiaratura, N. Ehrle, Efficacy of musical interventions in dementia: methodological requirements of nonpharmacological trials., Ann. N. Y. Acad. Sci. 1337 (2015) 249-255.

http://ovidsp.ovid.com/ovidweb.cgi?T=JS\&PAGE=reference $\& D=$ medl\&NEWS=N\& $\mathrm{AN}=25773641$.

[58] H. Park, J.K. Pringle Specht, Effect of individualized music on agitation in individuals with dementia who live at home., J. Gerontol. Nurs. 35 (2009) 47-55.

http://ovidsp.ovid.com/ovidweb.cgi?T=JS\&PAGE=reference $\& D=$ emed12\&NEWS $=\mathrm{N}$ $\& \mathrm{AN}=355388284$.

[59] A. Raglio, G. Bellelli, D. Traficante, M. Gianotti, M.C. Ubezio, S. Gentile, D. Villani, M. Trabucchi, Efficacy of music therapy treatment based on cycles of sessions: a randomised controlled trial... [corrected] [published erratum appears in AGING MENT HEALTH 2012; 16(2):265-7], Aging Ment. Health. 14 (2010) 900-904. doi:10.1080/13607861003713158.

[60] A. Raglio, D. Bellandi, P. Baiardi, M. Gianotti, M.C. Ubezio, E. Zanacchi, E. Granieri, M. Imbriani, M. Stramba-Badiale, Effect of Active Music Therapy and Individualized Listening to Music on Dementia: A Multicenter Randomized Controlled Trial, J. Am. Geriatr. Soc. 63 (2015) 1534-1539. http://www.blackwellpublishing.com/journal.asp?ref=0002-8614\&site=1 .

[61] A. Raglio, G. Bellelli, D. Traficante, M. Gianotti, M.C. Ubezio, D. Villani, M. 
Trabucchi, Efficacy of music therapy in the treatment of behavioral and psychiatric symptoms of dementia., Alzheimer Dis. Assoc. Disord. 22 (2008) 158-162.

http://ovidsp.ovid.com/ovidweb.cgi?T=JS\&PAGE=reference $\& D=$ med6\&NEWS $=\mathrm{N} \&$ $\mathrm{AN}=18525288$.

[62] K.D. Ray, M.S. Mittelman, Music therapy: A nonpharmacological approach to the care of agitation and depressive symptoms for nursing home residents with dementia.,

Dement. 16 (2017) 689-710. doi:10.1177/1471301215613779.

[63] M. Brotons, P. Marti, Music therapy with Alzheimer's patients and their family caregivers: a pilot project., J. Music Ther. 40 (2003) 138-150.

http://ovidsp.ovid.com/ovidweb.cgi?T=JS\&PAGE=reference $\& D=$ med4\&NEWS $=\mathrm{N} \&$ $\mathrm{AN}=14505442$.

[64] R. Remington, Calming music and hand massage with agitated elderly, Nurs. Res. 51 (2002) 317-323.

http://ovidsp.ovid.com/ovidweb.cgi?T=JS\&PAGE=reference $\& D=$ med4\&NEWS=N\& $\mathrm{AN}=12352780$.

[65] H.M.O. Ridder, B. Stige, L.G. Qvale, C. Gold, Individual music therapy for agitation in dementia: an exploratory randomized controlled trial., Aging Ment. Health. 17 (2013) 667-678. doi:10.1080/13607863.2013.790926.

[66] H.M. Ridder, D. Aldridge, Individual Music Therapy with Persons with Frontotemporal Dementia, Nord. J. Music Ther. 14 (2005) 91-106. doi:10.1080/08098130509478132.

[67] H.M. Ridder, T. Wigram, A.M. Ottesen, A pilot study on the effects of music therapy on frontotemporal dementia -- developing a research protocol., Nord. J. Music Ther. 18 (2009) 103-132. doi:10.1080/08098130903062371.

[68] S. Runci, C. Doyle, J. Redman, An empirical test of language-relevant interventions for dementia., Int. Psychogeriatrics. 11 (1999) 301-311. http://ovidsp.ovid.com/ovidweb.cgi?T=JS\&PAGE=reference $\& D=p s y c 3 \& N E W S=N \&$ $\mathrm{AN}=1999-11904-008$.

[69] M. Sakamoto, H. Ando, A. Tsutou, Comparing the effects of different individualized music interventions for elderly individuals with severe dementia, Int. Psychogeriatrics. 25 (2013) 775-784.

http://ovidsp.ovid.com/ovidweb.cgi?T=JS\&PAGE=reference $\& D=$ medl\&NEWS=N\& $\mathrm{AN}=23298693$.

[70] A. Sanchez, A. Maseda, M.P. Marante-Moar, C. de Labra, L. Lorenzo-Lopez, Comparing the Effects of Multisensory Stimulation and Individualized Music Sessions on Elderly People with Severe Dementia: A Randomized Controlled Trial., J. Alzheimer's Dis. 52 (2016) 303-315. doi:10.3233/JAD-151150.

[71] M. Satoh, T. Yuba, K. Tabei, Y. Okubo, H. Kida, H. Sakuma, H. Tomimoto, Music Therapy Using Singing Training Improves Psychomotor Speed in Patients with Alzheimer's Disease: A Neuropsychological and fMRI Study, Dement. Geriatr. Cogn. Dis. Extra. 5 (2015) 296-308. doi:10.1159/000436960.

[72] D.L. Shiltz, T.T. Lineweaver, T. Brimmer, A.C. Cairns, D.S. Halcomb, J. Juett, L. Beer, D.P. Hay, J. Plewes, "Music first": An alternative or adjunct to psychotropic medications for the behavioral and psychological symptoms of dementia., GeroPsych J. Gerontopsychology Geriatr. Psychiatry. 31 (2018) 17-30. doi:http://dx.doi.org/10.1024/1662-9647/a000180.

[73] H.-C. Sung, A.M. Chang, W. Lee, A preferred music listening intervention to reduce anxiety in older adults with dementia in nursing homes, J. Clin. Nurs. 19 (2010) 10561064.

http://ovidsp.ovid.com/ovidweb.cgi?T=JS\&PAGE=reference $\& D=$ med6\&NEWS=N\& 
$\mathrm{AN}=20492050$.

[74] M. Brotons, P.K. Pickett-Cooper, The effects of music therapy intervention on agitation behaviors of Alzheimer's disease patients., J. Music Ther. 33 (1996) 2-18. http://ovidsp.ovid.com/ovidweb.cgi?T=JS\&PAGE=reference $\& D=$ psyc3\&NEWS $=N \&$ $\mathrm{AN}=1996-03116-001$.

[75] H. Sung, W. Lee, T. Li, R. Watson, A group music intervention using percussion instruments with familiar music to reduce anxiety and agitation of institutionalized older adults with dementia., Int. J. Geriatr. Psychiatry. 27 (2012) 621-627. http://ovidsp.ovid.com/ovidweb.cgi?T=JS\&PAGE=reference $\& D=$ med7 \&NEWS $=\mathrm{N} \&$ $\mathrm{AN}=21823174$.

[76] M. Suzuki, M. Kanamori, M. Watanabe, S. Nagasawa, E. Kojima, H. Ooshiro, Behavioral and endocrinological evaluation of music therapy for elderly patients with dementia, Nurs. Heal. Sci. 6 (2004) 11-18.

http://ovidsp.ovid.com/ovidweb.cgi?T=JS\&PAGE=reference \&D=emed9\&NEWS=N\& AN=38396899.

[77] M. Suzuki, M. Kanamori, S. Nagasawa, I. Tokiko, S. Takayuki, Music therapyinduced changes in behavioral evaluations, and saliva chromogranin A and immunoglobulin A concentrations in elderly patients with senile dementia., Geriatr. Gerontol. Int. 7 (2007) 61-71.

http://ovidsp.ovid.com/ovidweb.cgi?T=JS\&PAGE=reference $\& D=p s y c 5 \& N E W S=N \&$ $\mathrm{AN}=2007-05822-005$.

[78] H.B. Svansdottir, J. Snaedal, Music therapy in moderate and severe dementia of Alzheimer's type: a case-control study., Int. Psychogeriatrics. 18 (2006) 613-621. http://ovidsp.ovid.com/ovidweb.cgi?T=JS\&PAGE=reference $\& D=$ med5\&NEWS=N\& $\mathrm{AN}=16618375$.

[79] T. PA, L. McKinnon-Howe, R. Remington, Effects of calming music on the level of agitation in cognitively impaired nursing home residents., Altern. Med. J. 2 (1995) $27-$ 32.

http://search.ebscohost.com/login.aspx?direct=true\&db=rzh\&AN=107133983\&site=e host-live.

[80] D.W. Thomas, R.J. Heitman, T. Alexander, The effects of music on bathing cooperation for residents with dementia., J. Music Ther. 34 (1997) 246-259. http://ovidsp.ovid.com/ovidweb.cgi?T=JS\&PAGE=reference $\& D=$ psyc $3 \& N E W S=N \&$ $\mathrm{AN}=1997-38507-002$.

[81] V. Valdiglesias, A. Maseda, L. Lorenzo-Lopez, E. Pasaro, J.C. Millan-Calenti, Is Salivary Chromogranin A a Valid Psychological Stress Biomarker During Sensory Stimulation in People with Advanced Dementia?, J. Alzheimer's Dis. 55 (2017) 15091517. doi:10.3233/JAD-160893.

[82] E.R. van der Geer, A.C. Vink, J.M.G.A. Schols, J.P.J. Slaets, Music in the nursing home: Hitting the right note! the provision of music to dementia patients with verbal and vocal agitation in Dutch nursing homes, Int. Psychogeriatrics. 21 (2009) 86-93. http://ovidsp.ovid.com/ovidweb.cgi?T=JS\&PAGE=reference $\& D=$ med6\&NEWS $=N \&$ $\mathrm{AN}=18947457$.

[83] A.C. Vink, M. Zuidersma, F. Boersma, P. De Jonge, S.U. Zuidema, J.P.J. Slaets, The effect of music therapy compared with general recreational activities in reducing agitation in people with dementia: A randomised controlled trial, Int. J. Geriatr. Psychiatry. 28 (2013) 1031-1038. doi:10.1002/gps.3924.

[84] J. Werner, T. Wosch, C. Gold, Effectiveness of group music therapy versus recreational group singing for depressive symptoms of elderly nursing home residents., Nord. J. Music Ther. 25 (2017) 147-155. doi:10.1080/13607863.2015.1093599. 
[85] E. Ceccato, G. Vigato, C. Bonetto, A. Bevilacqua, P. Pizziolo, S. Crociani, E. Zanfretta, L. Pollini, P.A. Caneva, C. Frongillo, A. Signorini, S. Demoro, E. Barchi, STAM protocol in dementia: a multicenter, single-blind, randomized, and controlled trial., Am. J. Alzheimers. Dis. Other Demen. 27 (2012) 301-310.

http://ovidsp.ovid.com/ovidweb.cgi?T=JS\&PAGE=reference $\& D=\operatorname{med} 7 \& N E W S=N \&$ $\mathrm{AN}=22815078$.

[86] N. Ziv, A. Granot, S. Hai, A. Dassa, I. Haimov, The effect of background stimulative music on behavior in Alzheimer's patients, J. Music Ther. 44 (2007) 329-343. http://ovidsp.ovid.com/ovidweb.cgi?T=JS\&PAGE=reference $\& D=$ emed11\&NEWS=N $\& \mathrm{AN}=351079788$.

[87] A.-N. Choi, M.S. Lee, K.-J. Cheong, J.-S. Lee, Effects of group music intervention on behavioral and psychological symptoms in patients with dementia: a pilot-controlled trial., Int. J. Neurosci. 119 (2009) 471-481.

http://ovidsp.ovid.com/ovidweb.cgi?T=JS\&PAGE=reference $\& D=$ emed12\&NEWS $=\mathrm{N}$ $\& \mathrm{AN}=354265226$.

[88] H. Chu, C.-Y. Yang, Y. Lin, K.-L. Ou, T.-Y. Lee, A.P. O’Brien, K.-R. Chou, The Impact of Group Music Therapy on Depression and Cognition in Elderly Persons With Dementia: A Randomized Controlled Study, Biol. Res. Nurs. 16 (2014) 209-217. http://ovidsp.ovid.com/ovidweb.cgi?T=JS\&PAGE=reference $\& D=$ emed16\&NEWS=N $\& \mathrm{AN}=1372478350$.

[89] H. Sung, W. Lee, T. Li, R. Watson, A group music intervention using percussion instruments with familiar music to reduce anxiety and agitation of institutionalized older adults with dementia., Int. J. Geriatr. Psychiatry. 27 (2012) 621-627. doi:10.1002/gps.2761.

[90] A.M. Cevasco, Effects of the therapist's nonverbal behavior on participation and affect of individuals with Alzheimer's disease during group music therapy sessions., J. Music Ther. 47 (2010) 282-299.

http://ovidsp.ovid.com/ovidweb.cgi?T=JS\&PAGE=reference $\& D=$ med6\&NEWS=N\& $\mathrm{AN}=21275336$.

[91] C.Y. Cheong, J.A.Q. Tan, Y.-L. Foong, H.M. Koh, D.Z.Y. Chen, J.J.C. Tan, C.J. Ng, P. Yap, Creative Music Therapy in an Acute Care Setting for Older Patients with Delirium and Dementia, Dement. Geriatr. Cogn. Dis. Extra. 6 (2016) 268-275. doi:10.1159/000445883.

[92] J. Cohen-Mansfield, M.S. Marx, L.. Freedman, H. Murad, K. Thein, What affects pleasure in persons with advanced stage dementia?, J. Psychiatr. Res. 46 (2012) 402406. http://www.elsevier.com/locate/jpsychires.

[93] J. Cohen-Mansfield, M.S. Marx, K. Thein, M. Dakheel-Ali, The impact of stimuli on affect in persons with dementia., J. Clin. Psychiatry. 72 (2011) 480-486. http://www.psychiatrist.com/privatepdf/2011/v72n04/v72n0407.Pdf.

[94] G. Engstrom, L.M. Hammar, C. Williams, E. Gotell, The impact of singing in caring for a person with dementia: Single case analysis of video recorded sessions., Music Med. 3 (2011) 95-101.

http://ovidsp.ovid.com/ovidweb.cgi?T=JS\&PAGE=reference $\& D=p s y c 8 \& N E W S=N \&$ AN=2011-13187-005.

[95] R. Groene, The effect of presentation and accompaniment styles on attentional and responsive behaviors of participantswith dementia diagnoses., J. Music Ther. 38 (2001) 36-50. http://ovidsp.ovid.com/ovidweb.cgi?T=JS\&PAGE=reference $\& D=$ med4\&NEWS=N\& $\mathrm{AN}=11407964$.

[96] R.I. Groene, S. Zapchenk, G. Marble, S. Kantar, The effect of therapist and activity 
characteristics on the purposeful responses of probable Alzheimer's disease participants., J. Music Ther. 35 (1998) 119-136.

http://ovidsp.ovid.com/ovidweb.cgi?T=JS\&PAGE=reference $\& D=$ psyc3\&NEWS=N\& $\mathrm{AN}=1998-04422-003$.

[97] N. Hanson, K. Gfeller, G. Woodworth, E.A. Swanson, L. Garand, A comparison of the effectiveness of differing types and difficulty of music activities in programming for older adults with Alzheimer's disease and related disorders., J. Music Ther. 33 (1996) 93-123.

http://ovidsp.ovid.com/ovidweb.cgi?T=JS\&PAGE=reference $\& D=p s y c 3 \& N E W S=N \&$ AN=1996-04776-002.

[98] C. Holmes, A. Knights, C. Dean, S. Hodkinson, V. Hopkins, Keep music live: Music and the alleviation of apathy in dementia subjects, Int. Psychogeriatrics. 18 (2006) 623-630.

http://ovidsp.ovid.com/ovidweb.cgi?T=JS\&PAGE=reference $\& D=$ med5\&NEWS=N\& $\mathrm{AN}=16805928$.

[99] C. Korb, The influence of music therapy on patients with a diagnosed dementia., Can. J. Music Ther. 5 (1997) 26-54.

http://ovidsp.ovid.com/ovidweb.cgi?T=JS\&PAGE=reference $\& D=p s y c 3 \& N E W S=N \&$ $\mathrm{AN}=1999-10019-001$.

[100] G.E. Lancioni, M.F. O’Reilly, N.N. Singh, J. Sigafoos, V. Rigante, L. De Franciscis, F. Stasolla, V. Perilli, R. Lang, A further evaluation of the impact of self-regulated music stimulation on positive participation of patients with Alzheimer's disease., J. Dev. Phys. Disabil. 25 (2013) 273-283.

http://ovidsp.ovid.com/ovidweb.cgi?T=JS\&PAGE=reference $\& D=p s y c 10 \& N E W S=N$ \&AN=2013-16626-001.

[101] G.E. Lancioni, N.N. Singh, M.F. O’Reilly, V.A. Green, G. Ferlisi, G. Ferrarese, V. Zullo, V. Perilli, G. Cassano, N. Cordiano, K. Pinto, N. Zonno, Self-regulated music stimulation for persons with Alzheimer's disease: impact assessment and social validation., Dev. Neurorehabil. 16 (2013) 17-26.

http://ovidsp.ovid.com/ovidweb.cgi?T=JS\&PAGE=reference $\& D=$ emed15\&NEWS $=\mathrm{N}$ \&AN=366313460.

[102] M.E. Christie, Music therapy applications in a skilled and intermediate care nursing home facility: A clinical study., Act. Adapt. Aging. 16 (1992) 69-87. http://ovidsp.ovid.com/ovidweb.cgi?T=JS\&PAGE=reference $\& D=$ psyc3\&NEWS $=N \&$ $\mathrm{AN}=1993-23102-001$.

[103] G.E. Lancioni, N.N. Singh, M.F. O’Reilly, J. Sigafoos, C. Renna, K. Pinto, F. De Vanna, A.O. Caffo, Persons with moderate Alzheimer's disease use simple technology aids to manage daily activities and leisure occupation., Res. Dev. Disabil. 35 (2014) 2117-2128. http://www.elsevier.com/locate/redevdis.

[104] R.M. Mathews, A.A. Clair, K. Kosloski, Brief in-service training in music therapy for activity aides: Increasing engagement of persons with dementia in rhythm activities., Act. Adapt. Aging. 24 (2001) 41-49. http://ovidsp.ovid.com/ovidweb.cgi?T=JS\&PAGE=reference $\& D=p s y c 3 \& N E W S=N \&$ AN=2000-13809-004.

[105] R. Melhuish, Group Music Therapy on a Dementia Assessment Ward: An Approach to Evaluation, Br. J. Music Ther. 27 (2013) 16-31. doi:10.1177/135945751302700103.

[106] N.J. Pollack, K.H. Namazi, The effect of music participation on the social behavior of Alzheimer's disease patients., J. Music Ther. 29 (1992) 54-67. http://ovidsp.ovid.com/ovidweb.cgi?T=JS\&PAGE=reference $\& D=p s y c 3 \& N E W S=N \&$ $\mathrm{AN}=1992-44199-001$. 
[107] H. Ragneskog, K. Asplund, M. Kihlgren, Individualized music played for agitated patients with dementia: analysis of video-recorded sessions, Int. J. Nurs. Pract. 7 (2001) 146-155.

http://ovidsp.ovid.com/ovidweb.cgi?T=JS\&PAGE=reference $\& D=e m e d 8 \& N E W S=N \&$ $\mathrm{AN}=35567153$.

[108] K. Sherratt, A. Thornton, C. Hatton, Emotional and behavioural responses to music in people with dementia: an observational study., Aging Ment. Health. 8 (2004) 233-241. http://ovidsp.ovid.com/ovidweb.cgi?T=JS\&PAGE=reference \&D=emed9\&NEWS=N\& $\mathrm{AN}=38639438$.

[109] M. van der Vleuten, A. Visser, L. Meeuwesen, The contribution of intimate live music performances to the quality of life for persons with dementia., Patient Educ. Couns. 89 (2012) 484-488.

http://ovidsp.ovid.com/ovidweb.cgi?T=JS\&PAGE=reference $\& D=$ med7 $\& N E W S=N \&$ $\mathrm{AN}=22742983$.

[110] M. Brotons, P. Pickett-Cooper, Preferences of Alzheimer's disease patients for music activities: Singing, instruments, dance/movement, games, and composition/improvisation., J. Music Ther. 31 (1994) 220-233. http://ovidsp.ovid.com/ovidweb.cgi?T=JS\&PAGE=reference $\& D=p s y c 3 \& N E W S=N \&$ $\mathrm{AN}=1995-14616-001$.

[111] A.A. Clair, R.M. Mathews, K. Kosloski, Assessment of active music participation as an indication of subsequent music making engagement for persons with midstage dementia., Am. J. Alzheimer's Dis. Other Dementias. 20 (2005) 37-40. http://search.ebscohost.com/login.aspx?direct=true \&db=rzh\&AN=106636865\&site $=e$ host-live.

[112] A.A. Clair, B. Bernstein, A preliminary study of music therapy programming for severely regressed persons with Alzheimer's-type dementia., J. Appl. Gerontol. 9 (1990) 299-311. http://ovidsp.ovid.com/ovidweb.cgi?T=JS\&PAGE=reference $\& D=p s y c 3 \& N E W S=N \&$ AN=1991-07777-001.

[113] A.A. Clair, The effect of singing on alert responses in persons with late stage dementia., J. Music Ther. 33 (1996) 234-247. doi:10.1093/jmt/33.4.234.

[114] A.A. Clair, The effects of music therapy on engagement in family caregiver and care receiver couples with dementia, Am. J. Alzheimers. Dis. Other Demen. 17 (2002) 286290.

http://ovidsp.ovid.com/ovidweb.cgi?T=JS\&PAGE=reference $\& D=e m e d 8 \& N E W S=N \&$ $\mathrm{AN}=35176061$.

[115] M. Clare, Soothing sounds: reducing agitation with music therapy., Nurs. Resid. Care. 16 (2014) 190-195.

http://search.ebscohost.com/login.aspx?direct=true \&db=rzh\&AN=103930186\&site=e host-live.

[116] A. Clements-Cortes, Singing for health, connection and care., Music Med. 7 (2015) $13-23$. http://ovidsp.ovid.com/ovidweb.cgi?T=JS\&PAGE=reference $\& D=p s y c 12 \& N E W S=N$ \&AN=2016-07315-003.

[117] J. Cohen-Mansfield, M.S. Marx, L.. Freedman, H. Murad, N.G. Regier, K. Thein, The comprehensive process model of engagement, Am. J. Geriatr. Psychiatry. 19 (2011) 859-870. http://ovidsp.ovid.com/ovidweb.cgi?T=JS\&PAGE=reference $\& D=$ emed13\&NEWS=N $\& A N=51165054$.

[118] M. Brotons, P. Marti, Music therapy with Alzheimer's patients and their family 
caregivers: a pilot project., J. Music Ther. 40 (2003) 138-150.

http://ovidsp.ovid.com/ovidweb.cgi?T=JS\&PAGE=reference $\& D=$ med4\&NEWS=N\& $\mathrm{AN}=14505442$.

[119] J. Davidson, R. Almeida, An exploratory study of the impact of group singing activities on lucidity, energy, focus, mood and relaxation for persons with dementia and their caregivers, Psychol. Well. Being. 4 (2014) 24. doi:10.1186/s13612-0140024-5.

[120] J.W. Davidson, J. Fedele, Investigating group singing activity with people with dementia and their caregivers: Problems and positive prospects., Music. Sci. 15 (2011) 402-422. doi:10.1177/1029864911410954.

[121] L.M. Hammar, A. Emami, E. Götell, G. Engström, The impact of caregivers' singing on expressions of emotion and resistance during morning care situations in persons with dementia: an intervention in dementia care., J. Clin. Nurs. 20 (2011) 969-978. http://ovidsp.ovid.com/ovidweb.cgi?T=JS\&PAGE=reference $\& D=\operatorname{med} 7 \& N E W S=N \&$ $\mathrm{AN}=21309873$.

[122] O. McDermott, V. Orgeta, H.M. Ridder, M. Orrell, A preliminary psychometric evaluation of Music in Dementia Assessment Scales (MiDAS), Int. Psychogeriatrics. 26 (2014) 1011-1019. doi:10.1017/S1041610214000180.

[123] A. Norberg, E. Melin, K. Asplund, Reactions to music, touch and object presentation in the final stage of dementia. An exploratory study., Int. J. Nurs. Stud. 23 (1986) 315323.

http://ovidsp.ovid.com/ovidweb.cgi?T=JS\&PAGE=reference \&D=emed9\&NEWS=N\& $\mathrm{AN}=37275968$.

[124] T. Särkämö, M. Tervaniemi, S. Laitinen, A. Numminen, M. Kurki, J.K. Johnson, P. Rantanen, Cognitive, Emotional, and Social Benefits of Regular Musical Activities in Early Dementia: Randomized Controlled Study., Gerontologist. 54 (2014) 634-650. doi:geront/gnt100.

[125] K. Smith-Marchese, The effects of participatory music on the reality orientation and sociability of Alzheimer's residents in a long-term-care setting., Act. Adapt. Aging. 18 (1994) 41-55.

http://ovidsp.ovid.com/ovidweb.cgi?T=JS\&PAGE=reference $\& D=p s y c 3 \& N E W S=N \&$ $\mathrm{AN}=1994-46631-001$.

[126] M. van der Vleuten, A. Visser, L. Meeuwesen, The contribution of intimate live music performances to the quality of life for persons with dementia., Patient Educ. Couns. 89 (2012) 484-488. doi:10.1016/j.pec.2012.05.012.

[127] A.A. Clements-Cortes, Buddy's Glee Club: Singing for life., Act. Adapt. Aging. 37 (2013) 273-290.

http://ovidsp.ovid.com/ovidweb.cgi?T=JS\&PAGE=reference $\& D=$ psyc10\&NEWS $=\mathrm{N}$ $\& A N=2013-43783-002$.

[128] S. Basaglia-Pappas, M. Laterza, C. Borg, A. Richard-Mornas, E. Favre, C. ThomasAnterion, Exploration of verbal and non-verbal semantic knowledge and autobiographical memories starting from popular songs in Alzheimer's disease., Int. Psychogeriatrics. 25 (2013) 785-795.

http://ovidsp.ovid.com/ovidweb.cgi?T=JS\&PAGE=reference $\& D=$ medl\&NEWS=N\& $\mathrm{AN}=23388499$.

[129] R.A. Bruer, E. Spitznagel, C.R. Cloninger, The temporal limits of cognitive change from music therapy in elderly persons with dementia or dementia-like cognitive impairment: A randomized controlled trial, J. Music Ther. 44 (2007) 308-328. http://ovidsp.ovid.com/ovidweb.cgi?T=JS\&PAGE=reference $\& D=$ med5\&NEWS=N\& $\mathrm{AN}=17997623$. 
[130] J.K. Johnson, G.L. Shaw, M. Vuong, S. Vuong, C.W. Cotman, Short-term improvement on a visual-spatial task after music listening in Alzheimer's disease: A group study., Act. Adapt. Aging. 26 (2002) 37-50.

http://ovidsp.ovid.com/ovidweb.cgi?T=JS\&PAGE=reference $\& D=$ psyc4\&NEWS=N\& $\mathrm{AN}=2002-06928-003$.

[131] J.J. Meilan Garcia, R. Iodice, J. Carro, J.A. Sanchez, Palmero, A.M. Mateos, Improvement of autobiographic memory recovery by means of sad music in Alzheimer's disease type dementia, Aging Clin. Exp. Res. 24 (2012) 227-232. http://www.kurtis.it/download/index.cfm?id=7874\&t=hres.

[132] A. Moussard, E. Bigand, S. Belleville, Music as a mnemonic to learn gesture sequences in normal aging and alzheimer'S disease, Front. Hum. Neurosci. 8 (2014) 1-9. http://journal.frontiersin.org/Article/DownloadFile/548020/FLPDF/fnhum-0800294.pdf.

[133] A. Moussard, E. Bigand, S. Belleville, I. Peretz, Learning sung lyrics aids retention in normal ageing and Alzheimer's disease., Neuropsychol. Rehabil. 24 (2014) 894-917. http://ovidsp.ovid.com/ovidweb.cgi?T=JS\&PAGE=reference $\& D=$ medl $\& N E W S=N \&$ $\mathrm{AN}=24881953$.

[134] F. Silber, The influence of background music on the performance of the Mini Mental State Examination with patients diagnosed with Alzheimer's disease., J. Music Ther. 36 (1999) 196-206.

http://ovidsp.ovid.com/ovidweb.cgi?T=JS\&PAGE=reference $\& D=p s y c 3 \& N E W S=N \&$ AN=1999-11856-002.

[135] N.R. Simmons-Stern, A.E. Budson, B.A. Ally, Music as a memory enhancer in patients with Alzheimer's disease, Neuropsychologia. 48 (2010) 3164-3167.

http://ovidsp.ovid.com/ovidweb.cgi?T=JS\&PAGE=reference $\& D=$ med6\&NEWS=N\& $\mathrm{AN}=20452365$.

[136] N.R. Simmons-Stern, R.G. Deason, B.J. Brandler, B.S. Frustace, M.K. O'Connor, B.A. Ally, A.E. Budson, Music-based memory enhancement in Alzheimer's Disease: Promise and limitations, Neuropsychologia. 50 (2012) 3295-3303. http://ovidsp.ovid.com/ovidweb.cgi?T=JS\&PAGE=reference $\& D=\operatorname{med} 7 \& N E W S=N \&$ $\mathrm{AN}=23000133$.

[137] R.G. Thompson, C.J.A. Moulin, S. Hayre, R.W. Jones, Music enhances category fluency in healthy older adults and Alzheimer's disease patients, Exp. Aging Res. 31 (2005) 91-99.

http://ovidsp.ovid.com/ovidweb.cgi?T=JS\&PAGE=reference $\& D=$ emed10\&NEWS=N \&AN=40069913.

[138] L.L. Cuddy, R. Sikka, K. Silveira, S. Bai, A. Vanstone, Music-evoked autobiographical memories (MEAMs) in Alzheimer disease: Evidence for a positivity effect., Cogent Psychol. 4 (2017). doi:http://dx.doi.org/10.1080/23311908.2016.1277578.

[139] M. El Haj, P. Antoine, J.L. Nandrino, M.-C. Gely-Nargeot, S. Raffard, Self-defining memories during exposure to music in Alzheimer's disease, Int. Psychogeriatrics. 27 (2015) 1719-1730. http://journals.cambridge.org/action/displayJournal?jid=IPG.

[140] M. El Haj, S. Clement, L. Fasotti, P. Allain, Effects of music on autobiographical verbal narration in Alzheimer's disease., J. Neurolinguistics. 26 (2013) 691-700. http://ovidsp.ovid.com/ovidweb.cgi?T=JS\&PAGE=reference $\& D=$ emed15\&NEWS $=\mathrm{N}$ $\& A N=369358108$.

[141] M. El Haj, V. Postal, A. Philippe, Music enhances autobiographical memory in mild Alzheimer's disease., Educ. Gerontol. 38 (2012) 30-41. http://ovidsp.ovid.com/ovidweb.cgi?T=JS\&PAGE=reference $\& D=p s y c 9 \& N E W S=N \&$ 
$\mathrm{AN}=2011-27113-004$.

[142] N.A. Foster, E.R. Valentine, The effect of auditory stimulation on autobiographical recall in dementia., Exp. Aging Res. 27 (2001) 215-228.

http://ovidsp.ovid.com/ovidweb.cgi?T=JS\&PAGE=reference $\& D=$ emed8\&NEWS=N\& $\mathrm{AN}=32624777$.

[143] A. Giovagnoli, V. Manfredi, A. Parente, L. Schifano, S. Oliveri, G. Avanzini, A.R. Giovagnoli, Cognitive training in Alzheimer's disease: a controlled randomized study, Neurol. Sci. 38 (2017) 1485-1493. doi:http://dx.doi.org/10.1007/s10072-017-3003-9.

[144] I.S. Hong, M.J. Choi, Songwriting oriented activities improve the cognitive functions of the aged with dementia., Arts Psychother. 38 (2011) 221-228.

http://ovidsp.ovid.com/ovidweb.cgi?T=JS\&PAGE=reference $\& D=$ emed13\&NEWS $=\mathrm{N}$ $\& \mathrm{AN}=51580388$.

[145] J.K. Johnson, C.W. Cotman, C.S. Tasaki, G.L. Shaw, Enhancement of spatial-temporal reasoning after a Mozart listening condition in Alzheimer's disease: a case study., Neurol. Res. 20 (1998) 666-672.

http://ovidsp.ovid.com/ovidweb.cgi?T=JS\&PAGE=reference \&D=emed7\&NEWS=N\& $\mathrm{AN}=28565443$.

[146] R.A. Bruer, E. Spitznagel, C.R. Cloninger, The temporal limits of cognitive change from music therapy in elderly persons with dementia or dementia-like cognitive impairment: a randomized controlled trial., J. Music Ther. 44 (2007) 308-328. http://ovidsp.ovid.com/ovidweb.cgi?T=JS\&PAGE=reference $\& D=$ med5\&NEWS $=\mathrm{N} \&$ $\mathrm{AN}=17997623$.

[147] A. Moussard, E. Bigand, S. Belleville, I. Peretz, Music as an aid to learn new verbal information in Alzheimer's disease., Music Percept. 29 (2012) 521-531.

http://ovidsp.ovid.com/ovidweb.cgi?T=JS\&PAGE=reference $\& D=p s y c 9 \& N E W S=N \&$ $\mathrm{AN}=2012-15378-007$.

[148] A.A. Clair, M. O'Konski, The effect of rhythmic auditory stimulation (RAS) on gait characteristics of cadence, velocity, and stride length in persons with late stage dementia., J. Music Ther. 43 (2006) 154-163.

http://ovidsp.ovid.com/ovidweb.cgi?T=JS\&PAGE=reference $\& D=$ med5\&NEWS=N\& $\mathrm{AN}=16897907$.

[149] H. Fukui, A. Arai, K. Toyoshima, Efficacy of music therapy in treatment for the patients with Alzheimer's disease, Int. J. Alzheimers. Dis. (2012) 1-6. doi:2012/531646.

[150] A. Wong, S. Burford, C.L. Wyles, H. Mundy, R. Sainsbury, Evaluation of strategies to improve nutrition in people with dementia in an assessment unit, J. Nutr. Health Aging. 12 (2008) 309-312. http://ovidsp.ovid.com/ovidweb.cgi?T=JS\&PAGE=reference $\& D=$ med6\&NEWS=N\& $\mathrm{AN}=18443712$.

[151] L.M. Gill, N.C. Englert, A Music Intervention's Effect on Falls in a Dementia Unit., J. Nurse Pract. 9 (2013) 562-567. doi:10.1016/j.nurpra.2013.05.005.

[152] A.M. Kumar, F. Tims, D.G. Cruess, M.J. Mintzer, G. Ironson, D. Loewenstein, R. Cattan, J.B. Fernandez, C. Eisdorfer, M. Kumar, Music therapy increases serum melatonin levels in patients with Alzheimer's disease., Altern. Ther. Health Med. 5 (1999) 49-57.

http://ovidsp.ovid.com/ovidweb.cgi?T=JS\&PAGE=reference $\& D=$ med4\&NEWS=N\& $\mathrm{AN}=10550905$.

[153] L. McHugh, S. Gardstrom, J. Hiller, M. Brewer, W.S. Diestelkamp, The effect of premeal, vocal re-creative music therapy on nutritional intake of residents with Alzheimer's disease and related dementias: A pilot study., Music Ther. Perspect. 30 
(2012) 32-42.

http://ovidsp.ovid.com/ovidweb.cgi?T=JS\&PAGE=reference $\& D=$ psyc9\&NEWS=N\& $\mathrm{AN}=2012-25301-006$.

[154] H. Ragneskog, M. Kihlgren, I. Karlsson, A. Norberg, Dinner music for demented patients: analysis of video-recorded observations., Clin. Nurs. Res. 5 (1996) 262-282. http://ovidsp.ovid.com/ovidweb.cgi?T=JS\&PAGE=reference $\& D=$ med4\&NEWS=N\& $\mathrm{AN}=8850771$.

[155] Y. Tanaka, H. Nogawa, Evaluating the Effects of Singing Songs in Ethnic Music Therapy for Dementia Patients with a Novel Near-infrared Spectroscopy (Data Analysis Method), Int. J. Gerontol. 9 (2015) 7-14. doi:10.1016/j.ijge.2014.01.006.

[156] Y. Tanaka, H. Nogawa, H. Tanaka, Music Therapy with Ethnic Music for Dementia Patients, Int. J. Gerontol. 6 (2012) 247-257. doi:10.1016/j.ijge.2012.01.026.

[157] D.W. Thomas, M. Smith, The effect of music on caloric consumption among nursing home residents with dementia of the Alzheimer's type., Act. Adapt. Aging. 33 (2009) $1-16$.

http://ovidsp.ovid.com/ovidweb.cgi?T=JS\&PAGE=reference \&D=psyc6\&NEWS=N\& $\mathrm{AN}=2009-04046-001$.

[158] J.E. Wittwer, K.E. Webster, K. Hill, Effect of rhythmic auditory cueing on gait in people with Alzheimer disease., Arch. Phys. Med. Rehabil. 94 (2013) 718-724. http://ovidsp.ovid.com/ovidweb.cgi?T=JS\&PAGE=reference \&D=medl\&NEWS=N\& $\mathrm{AN}=23159787$.

[159] L.A. Keough, B. King, T. Lemmerman, Assessment-Based Small-Group Music Therapy Programming for Individuals with Dementia and Alzheimer's Disease: A Multi-Year Clinical Project., Music Ther. Perspect. 35 (2017) 181-189. doi:10.1093/mtp/miw021.

[160] O. McDermott, M. Orrell, H.M. Ridder, The development of Music in Dementia Assessment Scales (MiDAS)., Nord. J. Music Ther. 24 (2015) 232-251. doi:10.1080/08098131.2014.907333.

[161] M. Sambandham, V. Schirm, Music as a nursing intervention for residents with Alzheimer's disease in long-term care, Geriatr. Nurs. 16 (1995) 79-83. http://ovidsp.ovid.com/ovidweb.cgi?T $=J S \& P A G E=$ reference $\& D=$ med3\&NEWS $=\mathrm{N} \&$ $\mathrm{AN}=7774824$.

[162] O. McDermott, M. Orrell, H.M. Ridder, The development of Music in Dementia Assessment Scales (MiDAS)., Nord. J. Music Ther. 24 (2015) 232-251. doi:10.1080/08098131.2014.907333.

[163] H.C. Kales, L.N. Gitlin, C.G. Lyketsos, Management of Neuropsychiatric Symptoms of Dementia in Clinical Settings: Recommendations from a Multidisciplinary Expert Panel, J. Am. Geriatr. Soc. 62 (2014) 762-769. doi:10.1111/jgs.12730.Management.

[164] V. Cotrell, R. Schulz, The Perspective of the Patient with Alzheimer' s Disease : A Neglected Dimension of Dementia Research 1, Gerontologist. 33 (1993) 205-211.

[165] T. DeNora, Music In Everyday Life, Cambridge University Press, Cambridge, 2000.

[166] O. McDermott, M. Orrell, H.M. Ridder, The importance of music for people with dementia: the perspectives of people with dementia, family carers, staff and music therapists., Aging Ment. Health. (2014). doi:10.1080/13607863.2013.875124.

[167] E. Johnston, X. Rasmusson, B. Foyil, P. Shopland, Witnesses to transformation: Family member experiences providing individualized music to their relatives with dementia, COGENT Educ. 4 (2017). doi:10.1080/2331186X.2017.1362888.

[168] L. Nygård, How can we get access to the experiences of people with dementia?, Scand. J. Occup. Ther. 13 (2006) 101-112. doi:10.1080/11038120600723190.

[169] K. Swaffer, Blog Post: Rethinking Dementia Care: \#BanBPSD, (2018). 
https://kateswaffer.com/2018/08/13/rethinking-dementia-care-banbpsd/ (accessed November 30, 2018). 